\title{
Assisted Reproductive Technologies and the Right to Reproduce under South African Law
}

\section{P.E.R}

Pioneer in peer-reviewed, open access online law publications

Author

Carmel van Niekerk

Affiliation

University of the Western Cape South Africa

Email cavanniekerk@uwc.ac.za

Date published

9 May 2017

Editor Dr A Gildenhuys

How to cite this article

Van Niekerk C "Assisted

Reproductive Technologies and the Right to Reproduce under South African Law" PER / PELJ 2017(20) - DOI

http://dx.doi.org/10.17159/17273781/2017/v20i0a1305

\section{Copyright}

DOI

http://dx.doi.org/10.17159/17273781/2017/v20i0a1305

\begin{abstract}
Reproductive rights in South Africa have traditionally focused on the rights of individuals to avoid reproduction. However, with an increase in the use of assisted reproductive technologies (ART), there has been a shift in the focus on reproductive rights from the rights of individuals to avoid reproduction to the rights of individuals to reproduce noncoitally.
\end{abstract}

With the emergence of new technologies, reproduction by noncoital means and the right to engage in these new technologies is becoming more prevalent. This raises two questions. The first question is whether such a right exists. The recent Constitutional Court decision in $A B$ v Minister of Social Development 20173 BCLR 267 (CC) suggests that it does, but only if the person claiming this right is physically involved in the reproductive process. Ostensibly this excludes those who cannot contribute to the reproduction of a child.

The second question raised pertains to the impact of this right on specific forms of ART, namely mitochondrial transfer, posthumous reproduction and embryo donation. While the first two forms of ART would meet the criteria set down in $A B$, embryo donation would not. Individuals denied access to embryo donation could thus not rely on either the right to reproductive autonomy or the right to privacy to aid them. Fortunately the existing legal framework provides some assistance to these individuals, although sadly the same legislative framework does not support the use of mitochondrial transfer and posthumous reproduction. In this respect there is incongruence between rights and legislation, which has only been exacerbated by the recent Constitutional Court decision. What is thus needed is clarity on the meaning of certain rights in respect of certain forms of ART as well as legislative reform to reflect the clarified position.

\section{Keywords}

Noncoital reproduction; right to reproduce; right to make decisions regarding reproduction; right to privacy; assisted reproductive technologies; mitochondrial donation; embryo donation; posthumous reproduction. 


\section{Introduction}

Reproductive rights ${ }^{1}$ in South Africa have traditionally focused on the rights of individuals to access contraceptives and sterilisation procedures, and to terminate pregnancies within the time frames stipulated by legislation. ${ }^{2}$ In other words, the focus historically has been on the right of individuals to avoid procreation. ${ }^{3}$ However, with an increase in the use of Assisted Reproductive Technologies (hereafter ART), there has been a shift in the focus on reproductive rights. ${ }^{4}$ The emphasis is now on the rights of individuals to reproduce noncoitally and the extent of their reproductive

* Carmel van Niekerk. LLB (UWC) LLM (Pret). Lecturer, Department of Private Law, University of the Western Cape. Email: cavanniekerk@uwc.ac.za. I am deeply indebted to Adv Donrich Jordaan for his input into this article

1 Reproductive rights include all rights that make it possible for an individual to reproduce or to refrain from reproducing. A more detailed definition of this term is provided at $s 3$ below.

2 This is evident from the legislation passed to date, which specifically recognises the right not to reproduce. See for example the Abortion and Sterilisation Act 2 of 1975, the Choice on Termination of Pregnancy Act 92 of 1996 and the Sterilisation Act 44 of 1998.

3 See generally Birenbaum 1996 SAJHR 485-503; Centre for Reproductive Rights 1998 http://www.reproductiverights.org/sites/default/files/documents/SRSouthAfrica98en.p df 6-9; Cohen and Sayeed $2011 \mathrm{~J}$ Law Med Ethics 235-242; Grossman et al 2011 BMC Health Services Research 224-232; Meyerson 1999 SALJ 50-59; Ngwena 2004 J Law Med Ethics 708-717; O'Sullivan "Reproductive Rights" 37-I - 37-28; Pickles 2012 PELJ 403-434; Sarkin-Hughes 1993 THRHR 83-94; Van Oosten 1999 SALJ 6076. See also Guttmacher et al 1998 Int Perspect Sex Reprod Health 191-194; Sidley 1998 http://www.bmj.com/content/316/7146/1696.2.full; Anon 1998 http://www.sahistory.org.za/dated-event/application-pretoria-supreme-court-declarefreedom-choice-terminate-pregnancy-law-uncons\#sthash.6n2PzNLG.dpuf; Anon 2004 http://www.news24.com/SouthAfrica/News/Teens-given-right-to-abortion20040528; Anon 2006 http://www.news24.com/SouthAfrica/Politics/Abortion-Actdeclared-invalid-20060817; and Anon 2008 http://www.news24.com/SouthAfrica/ Politics/Parliament-relaxes-abortion-law-20080207. That said, contraception and other means of avoiding procreation only became an issue amidst concerns regarding overpopulation. See for example Freedman and Isaacs 1993 Studies in Family Planning 21.

$4 \quad$ This has been occasioned by cases such as the recent decisions in $A B v$ Minister of Social Development 20162 SA 27 (GP) (hereafter $A B$ High Court case); and $A B v$ Minister of Social Development 20173 BCLR 267 (CC) (hereafter AB ConCourt case). 
freedom. ${ }^{5}$ As observed, rights mean very little unless supported by a legal framework which gives effect to these rights. ${ }^{6}$

In the light of ART's emphasis on the individual's reproductive rights, this article examines the international and local legal framework to determine whether it gives full effect to this right. This article is divided into four parts. After providing some background on ART and the definition of reproductive rights, the article proceeds to identify possible bases for such a right under international law. It then considers similar bases under South African law. It then evaluates existing legislation to determine whether such a right exists, and if it does, the extent to which the current legal framework gives effect to this right. The article then concludes by making recommendations for the way forward. But first, it is necessary to define ART and identify some of the advances occurring within this field.

\section{Assisted Reproductive Technologies (ART)}

ART was initially born out of a desire to assist individuals to overcome infertility. ${ }^{7}$ But what started out as an attempt to assist the infertile has over time morphed into a field that surpasses ordinary human expectation. Today ART can be used not only to eliminate infertility, but also for purposes of

$5 \quad$ "Noncoital" is defined by the Collins Dictionary as reproduction "not involving sexual intercourse". In some instances this type of reproduction may be referred to as "asexual reproduction". Collins Dictionary date unknown http://www.collinsdictionary.com/dictionary/english/noncoital. The former term is preferable to "asexual reproduction" as the latter is defined as "involving or reproducing by reproductive processes (as cell division, spore formation, fission, or budding) that do not involve the union of individuals or gametes" or as "[r]eproduction occurring without the sexual union of male and female gametes". See MerriamWebster date unknown http://www.merriam-webster.com/dictionary/asexual and Dictionary.com date unknown http://www.dictionary.com/browse/asexualreproduction. The latter term is problematic as it incorporates only certain forms of noncoital reproduction such as cloning where reproduction does not involve the union of gametes.

$6 \quad$ Olaniyan Corruption and Human Rights Law 172.

7 Bell 2006 AJETS 16. The WHO date unknown http://www.who.int/reproductivehealth/topics/infertility/definitions/en/_clinically defines infertility as "a disease of the reproductive system defined by the failure to achieve a clinical pregnancy after 12 months or more of regular unprotected sexual intercourse"; and as "the inability of a sexually active, non-contracepting couple to achieve pregnancy in one year". Kruger and Botha Clinical Gynaecology 337 define infertility (or subfertility, as it is also known) as "the inability to achieve pregnancy after one year of adequate sexual exposure". Asch and Marmor "Assisted Reproduction" 5 further define infertility as "an inability to sustain a pregnancy, which is demonstrated by repeat miscarriages". 
embryo research ${ }^{8}$ and pre-implantation genetic diagnosis (PGD). ${ }^{9}$ These developments within the field of ART have revolutionised how we perceive human reproduction. No longer is reproduction limited to sexual intercourse. Instead the range of technological advancements ${ }^{10}$ within this field as well as an increase in the rate of infertility ${ }^{11}$ has made noncoital reproduction a common occurrence. ${ }^{12}$

ART is defined as:

[a]ll treatments or procedures that include the in vitro handling of both human oocytes and sperm, or embryos, for the purpose of establishing a pregnancy. ${ }^{13}$

According to the definition provided by the World Health Organisation (hereafter the $\mathrm{WHO}$ ), these treatments or procedures include but are not limited to in vitro fertilisation ${ }^{14}$ and embryo transfer, ${ }^{15}$ gamete intrafallopian

8 Embryo research is conducted for one of the following reasons, using embryos donated by patients who have no need for them: To "[i]ncreas[e] the knowledge about serious disease or other serious conditions; [d]evelop treatments for serious diseases or other serious medical conditions; [i]ncreas[e] knowledge about the causes of congenital diseases; [p]romot[e] ... advances in the treatment of infertility; [i]ncreasing knowledge about the causes of miscarriages; [d]evelop more efficient techniques of contraception; [d]evelop methods for detecting gene, chromosome or mitochondrion abnormalities in embryos before implantation; and [i]ncreas[e] knowledge about the development of embryos". These are the purposes that have been identified by the Human Fertilisation and Embryology Authority 2012 http://www.hfea.gov.uk/161.html in the United Kingdom (UK).

$9 \quad$ PGD, which was initially offered only to couples at risk of transferring genetic and chromosomal disorders, is also available to infertile couples to determine the sources of repeated IVF failures and miscarriage. Bernabeu 2007 BIOforum Europe 2. Soini et al 2006 Eur J Hum Genet 590 distinguish PGD from IVF as follows "IVF aims at having a child, [while] PGD aims at having a healthy child".

10 Initially assisted reproduction was achieved by means of IVF. Since 1978, the range of options available to parties to address reproductive challenges has increased exponentially. See Al-Nuaim and Jenkins 2007 SAJOG 38-39.

11 According to a recent study conducted by the WHO, infertility currently affects $10.5 \%$ of individuals globally. See Mascarenhas et al 2012 PLOS Medicine 1. Kruger and Botha Clinical Gynaecology 337 note that $15-20 \%$ of the South African population struggles with infertility. This means that "one in every five to six couples" is infertile.

12 Snow and Knopff 2012 https://papers.ssrn.com/sol3/papers.cfm?abstract_id= 20564422.

13 WHO 2009 http://www.who.int/reproductivehealth/publications/infertility/art terminology.pdf.

14 This is an ART procedure that involves spontaneous fertilisation of an egg and sperm cell outside the human body. See the Definitions in the Regulations Relating to Artificial Fertilisation of Persons in GN 1165 in GG 40312 of 30 September 2016 (Regulations). These regulations were promulgated in terms of $s 68$ of the National Health Act 61 of 2003.

15 This procedure has been defined as "the placing of the embryo into the uterus or fallopian tube of the recipient". See the Definitions in the Regulations. 
transfer, ${ }^{16}$ zygote intrafallopian transfer, ${ }^{17}$ intracytoplasmic sperm injection, ${ }^{18}$ tubal embryo transfer, ${ }^{19}$ gamete and embryo cryopreservation, oocyte and embryo donation, and gestational surrogacy. ${ }^{20}$ Interestingly, this definition does not include artificial insemination using sperm from either a woman's partner or a donor. ${ }^{21}$

In each of these techniques gametes (ie the male and female reproductive cells) are handled outside the body to achieve reproduction. ${ }^{22}$ This handling of gametes may be for immediate use or for future use. ${ }^{23}$ In the latter

16 This is an ART procedure in which both gametes (oocytes and spermatozoa) are transferred to the Fallopian tubes.

17 This procedure involves a zygote or zygotes being transferred into the Fallopian tube. See WHO 2009 http://www.who.int/reproductivehealth/publications/infertility/art_ terminology.pdf.

18 This is a procedure in which a single spermatozoon is injected into the oocyte cytoplasm. See WHO 2009 http://www.who.int/reproductivehealth/publications/ infertility/art_terminology.pdf.

19 This procedure involves the transfer of an embryo(s) to the Fallopian tube. See the Definitions in the Regulations.

20 The definition provided by the WHO refers only to gestational surrogacy, but traditional surrogacy also involves some form of ART. The differences between the two forms of surrogacy are defined as follows: Gestational or full surrogacy describes those circumstances in which use is made of a surrogate mother but without recourse to her gametes, while traditional or partial surrogacy occurs where the surrogate provides both her gametes and her body as a conduit in the reproductive process. See Kindregan and McBrien Assisted Reproductive Technology 152-153.

21 Although there are alternate interpretations such as the one adopted by Kharb 2006 IJLHE 1, who includes artificial insemination under the umbrella of ART. This stance is similar to the one adopted in the definition of artificial fertilisation provided in the Regulations, which includes artificial insemination. Another interesting observation that can be made regarding this definition is that it includes only gestational surrogacy which involves using a surrogate but without having recourse to her gametes. This type of surrogacy is different from traditional surrogacy where the surrogate provides both her gametes and her body in the reproductive process. Both of these forms of surrogacy usually involve a medical procedure listed above. It is thus interesting that the one form is included while the other is not.

22 In vitro is defined as "extra corporeal" which means outside the body. WHO 2009 http://www.who.int/reproductivehealth/publications/infertility/art_terminology.pdf.

23 Cryopreservation makes this possible. Cryopreservation is defined as "the freezing or vitrification and storage of gametes, zygotes, embryos, or gonadal tissue." WHO 2009 http://www.who.int/reproductivehealth/publications/infertility/art_terminology.pdf. 
instance, the parties concerned may choose to cryopreserve their gametes $^{24}$ or have them fertilised in vitro for future use. ${ }^{25}$

In addition to being able to choose to use gametes or embryos now or in the future, individuals also have the option of using their own reproductive cells (where biology allows) or that of donors. ${ }^{26}$ While the use of gametes and embryos is generally unproblematic, ${ }^{27}$ this is not the case with mitochondrial donation, embryo donation and posthumous reproduction or conception (PHR). ${ }^{28}$ These forms of noncoital reproduction are arguably more contentious than other forms of noncoital reproduction ${ }^{29}$ and are explained next.

\subsection{Mitochondrial donation}

\section{Sometimes}

... mothers can carry abnormal mitochondria and be at risk of passing on serious disease[s] to their children, even if they themselves show only mild or no symptoms. It is for such women who by chance have a high proportion of faulty mitochondrial DNA in their eggs for which the methods of mitochondrial replacement or 'donation' have been developed. ${ }^{30}$

24 This scenario may for example present itself in instances where an individual is about to undergo cancer treatment which destroys reproductive cells. A trend has also started emerging among young career women who are extracting their eggs while they are in their twenties. Doing so allows them to focus on their careers until such time as they are ready to reproduce. The reason for this is that eggs are more viable the younger one is, which means that women who wait until they're older to procreate and do so naturally (ie without recourse to ART) may experience some difficulty in conceiving. In both of these instances the gametes are extracted and cryopreserved for later use. See for example Krans 2015 http://www.healthline.com/healthnews/women-freezing-eggs-so-they-can-work-now-and-have-kids-later-072015\#2;

Parry 2015 http://www.dailymail.co.uk/health/article-3078210/Number-womenfreezing-eggs-soars-400-one-year-careers-prioritised-motherhood.html; and Rushton 2014 http://www.telegraph.co.uk/finance/jobs/10681161/Women-are-freezing-theireggs-as-part-of-a-career-strategy.html.

25 This option is more commonly found in couples undergoing fertility treatment. Where gametes have been fertilised to create embryos, some of these embryos will be transferred to the recipient for procreation, while the remaining embryos may be stored for future use. At present reg 12 allows for the transfer of only three embryos at one time. This is the norm unless there is a medical reason to transfer more.

26 ASRM 2015 https://www.asrm.org/uploadedFiles/ ASRM_Content/Resources/Patient Resources/Fact_Sheets_and_Info_Booklets/ART.pdf 14 .

27 This may be the case as there are less likely to be additional parties involved in the reproductive process who may assert rights in respect of the child.

28 In each of these cases, matters are complicated by the added element of donation.

29 This is possibly because of the ethical concerns raised. The ethical concerns for each form of ART identified will be discussed below.

30 Human Fertilisation and Embryology Authority 2014 http://www.hfea.gov.uk/docs/2014-10-01_Mitochondrial_donation_an_introductory _briefing_note_-_final.pdf. 
This technique, which allows women to produce genetically-related offspring without transferring genetic defects, involves the removal of deoxyribonucleic acid (DNA)

... from a patient's egg or embryo containing unhealthy mitochondria to a donor's egg or embryo containing healthy mitochondria. ${ }^{31}$

This procedure is not currently allowed other than in the United Kingdom, which in 2015 passed legislation permitting research in this field. ${ }^{32}$ Mitochondrial donation has enormous legal implications which have yet to be resolved as it results in the production of a child with three genetic parents, ${ }^{33}$ instead of two. ${ }^{34}$ The process becomes even more complicated if it is used in conjunction with surrogacy, which is already complicated by the possibility of a third, fourth or fifth party in the reproductive process. ${ }^{35}$

\subsection{Embryo donation}

Embryo donation arises in instances where parties have fertilised their gametes but have elected to cryopreserve them for future use. ${ }^{36}$ Where these individuals later decide that they would not like to use the excess embryos themselves, they may choose to donate them to other parties, who will use them in the reproductive process. ${ }^{37}$ While this practice does raise some ethical ${ }^{38}$ and legal concerns $^{39}$ these are not insurmountable,

31 Human Fertilisation and Embryology Authority 2014 http://www.hfea.gov.uk/docs/2014-10-01_Mitochondrial_donation_an_introductory_ briefing_note_-_final.pdf.

32 Gallagher 2015 http://www.bbc.com/news/health-31594856; and Kelland and Maclellan $2015 \quad$ http://in.reuters.com/article/us-health-babies-idINKBNOL7 10B20150203.

33 These include the genetic mother, genetic father and the donor who contributed their healthy mitochondria.

34 Mitochondrial donation also raises serious ethical concerns. These include: concerns about safety, the creation of three-parent babies, the impact on a child's identity and the implications for society. Dimond 2015 British Medical Bulletin 175.

35 Fasouliotis and Schenker 1999 Human Reproduction Update 26. However, strictly speaking this may become possible in future in instances where a husband or wife is infertile, the other spouse is not, yet is a carrier for a life-threatening disease which they would prefer not to transfer to their offspring. In these instances mitochondrial donation of either the surrogate or a donor may provide the answer to producing a child that is at least partly connected to one of the commissioning parents.

36 Robertson 1995 Fertility and Sterility 885.

37 Robertson 1995 Fertility and Sterility 886.

38 Some of the ethical concerns include disclosure to the child, the mixing of embryos and gametes from different sources, and the issue of whether there should be compensation for donated embryos. See Robertson 1995 Fertility and Sterility 888890.

39 Some of the legal concerns include whether embryo donation should be treated as a gamete donation or an adoption; and what the status of the child is and the resultant rearing rights and duties that arise in this case. See Robertson 1995 Fertility and Sterility 890-893. 
according to Robertson. ${ }^{40}$ The most recent concerns regarding embryo donation involve instances where embryos are being made to order. ${ }^{41}$

\subsection{Posthumous Reproduction (PHR)}

PHR arises in instances where a party has donated his/her gametes prior to death and a recipient would like to use them thereafter. ${ }^{42}$ This generally occurs in instances where a spouse has stored his/her gametes for future use, but dies and the surviving spouse wants to use them ${ }^{43}$ or where a deceased child has donated its gametes to its parents and the parents wish to use the gametes to create grandchildren. ${ }^{44}$

In each of these instances the individuals concerned are presumably exercising a right to reproduce, albeit noncoitally. ${ }^{45}$ The question that needs to be answered is whether these forms of noncoital reproduction are protected under international law and South African law. In order to answer this question it is first necessary to define reproductive rights and to consider the extent to which these rights are protected both locally and internationally.

\section{Reproductive rights defined}

The term "reproductive rights" was first coined in $1984 .{ }^{46}$ The next time it was used was at the International Conference on Population and

$40 \quad$ Robertson 1995 Fertility and Sterility 893.

41 This practice alone raises a host of legal and ethical concerns. Rettner 2013 http://www.livescience.com/28652-made-to-order-embryos-legal-ethical-issues.html.

42 PHR occurs where a child is conceived "after the death of one or both genetic parents". See Kindregan and McBrien Assisted Reproductive Technology 251. Where consent has been obtained from the deceased, the ethical concerns regarding the violation of patient autonomy do not arise. Robey Posthumous Semen Retrieval and Reproduction 4-9 observes that this is, however, only one such concern. Others include the welfare of the child, the interests of the requesting party, as well as the interests of the physician. Orr and Siegler $2002 \mathrm{~J} \mathrm{Med} \mathrm{Ethics} 299$ identify only consent, respectful treatment of the dead body, and the potential welfare of the child as possible ethical concerns.

43 Kindregan and McBrien 2005 Fam L Q 580 note that "it is increasingly common for men, for example, to store sperm for potential use by a wife or a girlfriend in the event of their deaths. Soldiers who are assigned to combat zones, men who have cancer or other terminal illnesses, or athletes and others engaged in dangerous activities might also elect to have their sperm cryopreserved."

44 This is the case with Sharon Duncan, whose son, Cameron, donated his sperm to her on his death in 2003. See Mussen 2015 http://www.stuff.co.nz/ national/health/67539030/hope-for-dead-teens-sperm.

45 I say presumably as the existence of this right forms part of my doctoral research, which is ongoing.

46 This took place at the $1^{\text {st }}$ International meeting on Women and Health in Amsterdam. See Davis Mattar 2008 SUR - International Journal on Human Rights 63. 
Development (ICPD) in Cairo in $1994^{47}$ and thereafter at the Beijing Declaration and Platform for Action, Fourth World Conference on Women on 15 September $1995 .{ }^{48}$ According to the ICPD Programme of Action:

[R]eproductive rights embrace certain human rights that are already recognised in national laws, international human rights documents and other consensus documents. These rights rest on the recognition of the basic right of all couples and individuals to decide freely and responsibly the number, spacing and timing of their children and to have the information and means to do so, and the right to attain the highest standard of sexual and reproductive health. It also includes their right to make decisions concerning reproduction free from discrimination, coercion and violence, as expressed in human rights documents. ${ }^{49}$

According to this definition reproductive rights may not be provided for expressly. ${ }^{50}$ Instead they may be inferred from other rights that are already in existence. These existing rights include (but are not limited to) the right to make decisions regarding reproduction (or reproductive freedom), the right to non-discrimination and equal treatment, the right to information and the right to the highest standard of health. ${ }^{51}$

In respect of the right to reproductive freedom, Blank suggests that these decisions typically fall into three categories. ${ }^{52}$ These include deciding to have children, deciding not to do so, and deciding to have children of a particular quality and quantity. ${ }^{53}$ The first category has been interpreted as including the acquisition of children by adoption and by means of natural

47 This conference was coordinated by the United Nations with the aim of creating a document, the Programme of Action, which would direct the United Nations Population Fund in its future approaches on population development.

48 This conference was arranged by the United Nations Commission on the Status of Women. It was at this conference that the Commission adopted the Beijing Declaration and Platform for Action, which identified twelve areas of concern regarding women. See generally UN Women date unknown http://www.un. org/womenwatch/daw/beijing/.

49 UN Population Fund 2014 http://www.unfpa.org/sites/default/files/pubpdf/programme_of_action_Web\%20ENGLISH.pdf para 7.3.

50 In other words there is no right to procreate or to avoid procreation. Instead these rights are manifestations of the rights mentioned above. This is confirmed by Packer Right to Reproductive Choice 14, who notes that reproductive rights do not exist "expressis verbis". Instead the term "reproductive rights" is a "shorthand way of referring to the 'right to decide freely and responsibly on the number and spacing of [one's] children and to have access to information, education and means to enable [one] to exercise these rights' - rights which are provided expressis verbis in an international human rights treaty".

51 Shalev 2000 Health and Human Rights 40, in particular, identifies personal autonomy and the right to equality as providing, either directly or indirectly, for the rights to sexual and reproductive health.

52 Blank 1997 Politics and the Life Sciences 280.

53 Blank 1997 Politics and the Life Sciences 280. 
conception. ${ }^{54}$ The second category, which amounts to a decision to avoid reproduction, includes choosing to use contraceptives, terminating a pregnancy or being sterilised voluntarily. ${ }^{55}$ The third category, which is arguably merely an extension of the first,$^{56}$ distinguishes between deciding on the quantity of children and the quality of children. The first component of this category is generally accepted in most human rights instruments, ${ }^{57}$ while the second component has only recently received attention due to advancements in medical science. ${ }^{58} \mathrm{It}$ is this second component that is quite contentious and will be discussed in greater detail below.

PHR could arguably fall into the first category, ${ }^{59}$ while mitochondrial donation and reproduction using donated embryos would potentially fall into the third category. ${ }^{60}$

\section{Reproductive rights under international law}

Under international law, a distinction can be made between general provisions that recognise reproductive rights and specific provisions that recognise these rights. General provisions include the right to privacy and family life. Manifestations of this right can be found in Article 17(1) of the International Covenant on Civil and Political Rights (ICCPR) (1966) ${ }^{61}$ and Article 8(1) of the European Convention for the Protection of Human Rights and Fundamental Freedoms (ECHR) (1950). ${ }^{62}$ Within the context of reproduction, this right has been interpreted by the European Court of

54 It has yet to be determined whether this decision includes acquiring children by means of noncoital reproduction.

55 Here a distinction must be made with coercive sterilisation, which is not an exercise of the right not to reproduce but a limitation of the right to reproduce.

56 This is because parties first need to decide to have children, before they can make a decision regarding the quality and quantity of their prospective offspring.

57 For a discussion, see $\mathrm{s} 4$ below.

58 An example of such advancement is karyomapping, which is used to detect and eliminate genetic abnormalities to allow "couples to avoid passing [a] disorder on to their offspring". See Illumina 2014 http://www.illumina.com/content/dam/illuminamarketing/documents/clinical/karyomapping -clinicians.pdf.

59 PHR is an expression of the decision to have children.

60 Mitochondrial donation is a case of deciding on the quality of one's offspring, while reproducing by means of donated embryos amounts to a decision regarding the quantity of one's offspring.

61 International Covenant on Civil and Political Rights (ICCPR) (1966) art 17(1) states that "No one shall be subjected to arbitrary or unlawful interference with his privacy, family, home or correspondence, nor to unlawful attacks on his honour and reputation".

62 European Convention for the Protection of Human Rights and Fundamental Freedoms (ECHR) (1950) art 8(1) recognised that "Everyone has the right to respect for his private and family life, his home and his correspondence". 
Human Rights (ECtHR) as "incorporat[ing] the right to respect for both the decisions to become and not to become a parent". ${ }^{63}$

Specific provisions that recognise reproductive rights include the right of individuals to found a family. This right has been interpreted as going

... beyond the right to conceive, gestate and deliver a child; it involves the right of the couple to decide whether or not to have children, when to have them, and the space between them. ${ }^{64}$

This right has found expression in a number of international human rights instruments such as Article 16 of the Universal Declaration of Human Rights (UDHR) (1948), ${ }^{65}$ Article 23(2) of the ICCPR, ${ }^{66}$ Article 18 of the African Charter on Human and Peoples' Rights (ACHPR) (1981) ${ }^{67}$ and Article 12 of the ECHR. ${ }^{6} 8$

Other provisions that specifically recognise the right to reproduce can be found in provisions such as Article 16(1)(e) of the Convention on the Elimination of All forms of Discrimination against Women (CEDAW) (1979), ${ }^{69}$ which obliges States Parties to

... take all appropriate measures to eliminate discrimination against women in all matters relating to marriage and family relations and in particular shall ensure, on a basis of equality of men and women:

(e) The same rights to decide freely and responsibly on the number and spacing of their children and to have access to the information, education and means to enable them to exercise these rights.

63 Evans $v$ the United Kingdom Application No 6339/05 of 10 April 2007 para 71.

64 UN 2014 http://www.ohchr.org/Documents/Publications/NHRIHandbook.pdf 104.

65 Universal Declaration on Human Rights (1948) art 16 provides: "(1) Men and women of full age, without any limitation due to race, nationality or religion, have the right to marry and to found a family. They are entitled to equal rights as to marriage, during marriage and at its dissolution".

66 ICCPR art 23(2) states that "[t]he right of men and women of marriageable age to marry and to found a family shall be recognised". Emphasis added.

67 African Charter on Human and Peoples' Rights (1981) art 18(1) recognises that "The family shall be the natural unit and basis of society. It shall be protected by the State which shall take care of its physical health and moral". The protection afforded in this provision differs somewhat from the other instruments that protect the right to found a family.

68 ECHR art 12 states that "[m]en and women of marriageable age have the right to marry and to found a family, according to the national laws governing the exercise of this right".

69 Convention on the Elimination of All Forms of Discrimination against Women (1979) art 16 provides: "1. States Parties shall take all appropriate measures to eliminate discrimination against women in all matters relating to marriage and family relations and in particular shall ensure, on a basis of equality of men and women: (e) The same rights to decide freely and responsibly on the number and spacing of their children and to have access to the information, education and means to enable them to exercise these rights...." 
Interestingly, the only court to consider the application of these rights within the realm of noncoital reproduction has been the ECtHR. For example, in Dickson $v$ United Kingdom, ${ }^{70}$ the ECtHR found that a person's right to use artificial insemination falls within the ambit of the Article 8 of the ECHR, which protects the right to respect for private and family life. While the plaintiff relied on both Article 8 and Article 12 (which protects the right to marry and found a family), the court did not feel the need to address the claim under Article 12 once it had found a violation of Article 8 . The decision in this case suggests, in the absence of evidence to the contrary, that noncoital reproduction may fall within the ambit of this right, more than any other. It is worth noting that similar cases involving noncoital reproduction also centred on the right contained in Article $8 .^{71}$ It is unclear, however, whether noncoital reproduction would similarly find protection under the right to found a family.

In respect of the three instances of noncoital reproduction that form the focus of this article, there is no case law to confirm that the right to privacy, or any other reproductive right for that matter, extends to mitochondrial donation. However, in Costa and Pavan $v$ Italy, ${ }^{72}$ which involved an Italian couple

... who are healthy carriers of cystic fibrosis and wanted, with the help of medically-assisted procreation and genetic screening, to avoid transmitting the disease to their offspring, the Court held that there had been a violation of Article $8 .{ }^{73}$

The argument could thus be made that this right could similarly extend to mitochondrial donation. In the same vein it could be argued that legislation that prohibits PHR constitutes a violation of the right to private and family life. This form of noncoital reproduction is, however, more complex, as it is dependent on the consent of the deceased person. ${ }^{74}$ Where such consent has been given, it could be argued that a refusal to allow reproduction violates the applicant's rights. The converse would be true where such consent has not been obtained. ${ }^{75}$ Unfortunately, foreign case law on this

70 Dickson $v$ the United Kingdom Application No 44362/04 of 4 December 2007 para 66.

71 See for example Evans $v$ the United Kingdom Application No 6339/05 of 10 April 2007; SH v Austria Application No 57813/00 of 3 November 2011; Parrillo v Italy Application No 46470/11 of 27 August 2015; Knecht $v$ Romania Application No 10048/10 of 2 October 2012; Nedescu v Romania Application No 70035/10 of 6 November 2012.

72 Costa and Pavan v Italy Application No 54270/10 of 28 August 2012.

73 ECtHR 2015 http://www.echr.coe.int/Documents/FS_Reproductive_ENG.pdf.

74 Kindregan and McBrien 2005 Fam L Q 595.

75 Because PHR in most cases hinges on the consent of the deceased, courts will refuse the retrieval of gametes where such consent has not been obtain. This was the case in $R v$ Human Fertilisation and Embryology Authority, ex $p$ Blood 19963 WLR 1176 (QB) where the deceased's sperm was retrieved before he was declared "clinically 
issue is unhelpful as most courts have based their decisions on contract principles rather than on the violation of reproductive rights. ${ }^{76}$

Then, in respect of the rights of recipients of donor embryos, it is equally uncertain whether this exercise of reproductive rights would fall within the scope of the right to privacy and family life. However, in Parrillo $v$ Italy, ${ }^{77}$ the ECtHR found that a woman's decision to donate her excess embryos to scientific research did not constitute a violation of her Article 8 right. The challenge posed by embryo donation is that there are potentially two sets of individuals' rights that are at stake. ${ }^{78}$ To date the emphasis has been on the rights of the donor and not the recipients. ${ }^{79}$ This poses the question whether the reproductive rights of recipients are equal to or inferior to those of the donors. ${ }^{80}$

In the light of the aforementioned it can be concluded that even at an international level, while provisions do exist which recognise individual's reproductive rights, some may not be comprehensive enough to recognise an individual's right to make use of ART to facilitate reproduction in all the ways mentioned in this article. This raises the question whether South African law is any different. To answer this question, the legal position in South Africa will be considered next.

\section{$5 \quad$ Reproductive rights under South African law}

The legislative history of reproductive rights in South African can be divided into three phases: legislation prior to 1996, the Constitution of the Republic of South Africa, 1996 (hereafter the Constitution) and legislation after 1996.

dead". In this instance the court would not permit his wife to use the sperm as he had not consented prior to his death. According to Peart 2015 VUWLR 746 the retrieval of the sperm without his consent was "[t]echnically ... an offence under the Human Fertilisation and Embryology Act 1990 (UK), ss 4(1)(a), 12 and 41".

76 See for example $R$ (on the application of $M$ ) $v$ Human Fertilisation and Embryology Authority 2015 EWHC 1706 (Admin); L v Human Fertilisation and Embryology Authority 2008 EWHC 2149 (Fam); and Re Edwards 2011 NSWSC 478, 201181 NSWLR 198.

77 Parrillo $v$ Italy Application No 46470/11 of 27 August 2015.

78 Namely those of the donors and those of the recipients.

79 This is evident from decisions such as Parrillo $v$ Italy where the rights of the donor form the focal point. One could almost conclude that the recipients do not have any rights.

80 This question will not be considered in this article. Instead it forms part of an ongoing study. 


\subsection{Legislation prior to 1996}

Prior to the promulgation of the Constitution, legislation pertaining to reproduction consisted primarily of the Abortion and Sterilisation Act..$^{81}$ This Act for the first time permitted pregnancies to be terminated legally. Although the Act had been intended to prevent persons from obtaining "clandestine abortions", ${ }^{82}$ it had the opposite effect, as its provisions permitting abortion were so narrowly formulated that "the new law actually made it more difficult to procure abortions". ${ }^{83}$ The result of this was that reproductive rights were narrowly interpreted and recognised only the right not to have children in limited circumstances. ${ }^{84}$

\subsection{The 1996 Constitution}

With the advent of the Constitution, reproductive rights have found protection under section 12(2)(a), which recognises the rights of everyone ${ }^{85}$ to make decisions regarding reproduction. In each case dealing specifically with this provision, this right has been interpreted as affording individuals the right not to reproduce by means of access to terminations of pregnancy. ${ }^{86}$ Evidence of this can be found in both the Christian Lawyers Association of SA v Minister of Health cases, ${ }^{87}$ where the court recognised the application of the right in section 12(2)(a) within the context of a termination of pregnancy.

In the recent decision of the Gauteng High Court in $A B \vee$ Minister of Social Development $(A B),{ }^{88}$ where the applicant sought an order declaring section 294 of the Children's Act inconsistent with the Constitution and therefore unconstitutional on the basis that it prohibited her from using surrogacy as a means of becoming a parent and therefore violated her rights to privacy, reproductive autonomy, dignity, equality and access to healthcare, a South African court for the first time considered these rights within the ambit of noncoital reproduction. In this instance the court found in the applicant's

81 Abortion and Sterilisation Act 2 of 1975. Before this there was no legislation which regulated abortion or any form of reproductive choice. See Rebouche 2011 Ala L Rev 4.

82 Guttmacher et al 1998 Int Perspect Sex Reprod Health 191.

83 Guttmacher et al 1998 Int Perspect Sex Reprod Health 192.

84 Guttmacher et al 1998 Int Perspect Sex Reprod Health 192.

85 Emphasis added.

86 O'Sullivan "Reproductive Rights" 37-15.

87 Christian Lawyers Association of SA v Minister of Health 19984 SA 1113 (T) and Christian Lawyers Association v Minister of Health 20051 SA 509 (T). In the latter case the court considered whether a girl under the age of 18 years, in exercising her rights in $\mathrm{s} 12(2)(\mathrm{a})$, could terminate her pregnancy without parental consent. 
favour. ${ }^{89}$ This judgment effectively confirmed that reproductive autonomy, which finds protection under section 12(2)(a) of the Constitution, includes noncoital reproduction as well. ${ }^{90}$ However, the later decision by the majority of the Constitutional Court had a different outcome. In this decision the majority found that section 294 does not violate the applicant's right to reproductive autonomy as the right contained in section 12(2)(a) pertains to an individual's own body and not that of another woman. ${ }^{91}$ The attack on section 294 thus failed. The implication of this decision is that while section 12(2)(a) protects the right to reproduce noncoitally, it does so only if the parties themselves are physically involved in the reproductive process, ${ }^{92}$ presumably either by providing genetic material or by carrying the child. This effectively excludes individuals who cannot meet these criteria. As far as mitochondrial transfer and posthumous reproduction are concerned, these criteria would ostensibly be met. In each of these cases the parties concerned would provide the genetic material for the specific form of ART. Embryo donation is a different case as the recipients would not have the requisite genetic material but may be able to provide the womb required. ${ }^{93}$

From the aforementioned it becomes apparent that the right to reproductive autonomy as contained in section 12(2)(a) is available to everyone ${ }^{94}$ provided that their own bodies are engaged in the act of reproduction. This finding raises a number of concerns. The first relates to the right to psychological integrity and the second relates to the fixation regarding the use of one's own gametes. As far as the first issue is concerned, reference is made to the wording of section 12(2) of the Constitution which protects the right to bodily and psychological integrity. The majority of the Constitutional Court appears to have conflated these concepts into one. Is it not possible that legislation which prevents an individual from exercising their choice in respect of reproduction, can impact on their psychological integrity without necessarily having a similar impact on their bodily integrity? For a long time the psyche was not thought of as being part of the body. ${ }^{95}$ The reference to both bodily and psychological integrity could as such serve as recognition that both the body and the psyche are protected. This is not

$89 \quad A B$ ConCourt case para 15.

90 This is consistent with the views of Van Niekerk 2015 PELJ 405, who observes that there is nothing in the wording of $s 12(2(a)$ to suggest that the right includes only reproduction by natural means or that it is available to fertile individuals only.

$91 \quad A B$ ConCourt case para 313.

$92 \quad A B$ ConCourt case paras 314-315.

93 In certain instances of embryo donation, the recipient may not be able to provide the genetic material but may be able to provide the uterus "to undergo pregnancy and childbirth". Robertson 1995 Fertility and Sterility 885.

$94 \quad$ Emphasis added.

95 Loubser and Midgley Law of Delict 47, 306. 
to say that the two terms are synonymous and that an infringement of one automatically translates into an infringement of the other. While this may be true of the body, the same is not true of the psyche. So while it is possible to inflict harm in a way that infringes both one's bodily integrity as well as one's psychological integrity, it is equally possible that only one's psychological integrity is compromised without an accompanying infringement of one's bodily integrity. A number of cases have recognised and awarded damages to the victims of such harm. ${ }^{96}$ To now find otherwise would render decades of case law redundant. Based on a violation of psychological integrity alone, the applicant's claim in $A B$ should thus have succeeded.

As far as the second issue is concerned, the provision in section 12(2)(b) is different from provision in paragraph (a). While paragraph (b) specifically makes reference to "security in and control over their body", paragraph (a) contains no similar requirement. Ostensibly, making a decision regarding reproduction may thus involve the assistance of others in the reproductive process. ${ }^{97}$ The need to provide one's own gametes would thus be unnecessary in these circumstances. ${ }^{98}$ If the interpretation adopted by the majority is to be followed, then all forms of noncoital reproduction are not protected by section 12(2)(a). This suggests that this provision is not flexible enough to accommodate advancements in medical technology and may thus need to be amended or at the very least be interpreted more broadly in future. Sadly, while the majority in the Constitutional Court recognised that this case provided it with the "first opportunity to vindicate" the right contained in section 12(2)(a) within the context of surrogacy, ${ }^{99}$ it did a poor job of doing so. So where does this leave individuals like the applicant in $A B$ ?

The only other possible alternative would be a reliance on the right to privacy, which was the approach adopted in the ECtHR. This right, which is

96 See for example Road Accident Fund $v$ Sauls 20022 SA 55 (SCA); Majiet $v$ Santam Ltd 19974 All SA 555 (C); Barnard v Santam Bpk 19991 SA 202 (SCA); and ClintonParker v Administrator, Transvaal; Dawkins v Administrator, Transvaal 19962 SA 37 (W).

97 Provided that an individual is able to engage others to reproduce on their behalf, without coercion and with their consent, the provision in paragraph (a) would be satisfied.

98 The fixation with using one's own gametes does not make sense when medical science makes it possible to reproduce with assistance. This position is to be distinguished from the choice exercised in cases of terminations of pregnancy which is also protected under s 12(2)(a) and which is dependent on the individual being pregnant personally. The existence of ART does not require one to be pregnant or to contribute personally in the reproductive process. 
not framed in exactly the same way as Article 8, is protected under section 14 of the Constitution, ${ }^{100}$ which contains two parts. The first "guarantees a general right to privacy, [while] the second [part] protects against specific enumerated infringements of privacy". ${ }^{101}$ It is the first part which would be applicable in the context of noncoital reproduction. In this respect the right to privacy would relate to choice, ${ }^{102}$ in particular "the right to make a choice without state interference". ${ }^{103}$ This right has on two occasions been interpreted by the Constitutional Court as "encompass[ing] the right of a person to live his or her life as he or she pleases, and not to be interfered with". ${ }^{104}$ Presumably choosing to engage in a particular form of noncoital reproduction falls within the ambit of this right. At least, the Gauteng High Court thought so when it found that

... the commissioning parent(s) decision to use donor gametes for the conception of their prospective children and acting on such decision falls within the realm of privacy and accordingly within the ambit of protection of the constitutional right to privacy. ${ }^{105}$

However, the majority judgment in the Constitutional Court disagreed. It found that section 294 does not limit the applicant's right to privacy. ${ }^{106}$ This then excludes access to ART on the basis of the right to privacy. In this respect the Constitutional Court was wrong. How can one advocate that a particular right allows one to live his or her life as he or she pleases and then suggest that he or she alter that choice to bring himself or herself within the ambit of a legislative provision. ${ }^{107}$ This is contrary to previous interpretations of that right as well as previous jurisprudence ${ }^{108}$ that has specifically recognised various family forms in South Africa. ${ }^{109}$ This decision is an opportunity to reflect on the meaning of the right to privacy and whether the meaning once attributed to this term is no longer applicable.

\footnotetext{
100 This provision recognises that "[e]veryone has the right to privacy".

101 Currie and De Waal Bill of Rights Handbook 294.

102 Van der Bank 2012 EJBSS (citing Kang) 77 suggests that privacy can be divided into three "clusters", namely "spatial privacy [which refers to] the extent to which a person's individual territorial space is shielded from invasion; privacy related to choice; and privacy relating to flow of personal information".

103 Van der Bank 2012 EJBSS 78.

104 Bernstein v Bester 19962 SA 751 (CC) para 73; and NMv Smith 20075 SA 250 (CC) para 33.

$105 \quad A B$ High Court case para 95.

$106 \quad A B$ ConCourt case para 323.

$107 \quad A B$ ConCourt case para 288.

108 See Bernstein v Bester 19962 SA 751 (CC) para 73; and NM v Smith 20075 SA 250 (CC) para 33.

109 Minister of Home Affairs v Fourie 20061 SA 524 (CC) para 59.
} 
The reality is that section 294 of the Children's Act violates the rights of individuals to exercise their reproductive choice and to do so freely. The limitations of these rights are not reasonable and justifiable and in this respect I am compelled to agree with the minority judgment. ${ }^{110}$ The internal mechanisms for surrogacy agreements which are regulated by the Children's Act serve as a filter for unsuitable candidates. ${ }^{111}$ The applicant in $A B$ should at least have been awarded the same opportunity as others to exercise her reproductive autonomy. Whether or not she would be successful in carrying out her decision is another matter entirely, as section 12(2)(a) does not guarantee the right to give effect to a decision, ${ }^{112}$ merely to make one. In this respect, the Constitutional Court failed her.

Despite the recent judgment, it is submitted that a denial of certain forms of noncoital reproduction do constitute a violation of privacy. This would be consistent with the approach adopted by the ECtHR. In this respect South Africa took a step backwards as far as the interpretation of certain rights is concerned. What is thus needed is an exploration of the meaning of these rights within the context of noncoital reproduction.

\subsection{Legislation after 1996}

Since the Constitution entered into force, a number of acts have been passed which give effect to the right contained in section 12(2)(a). ${ }^{113}$ The first two Acts, namely, the Choice on Termination of Pregnancy Act (Choice Act) ${ }^{114}$ and the Sterilisation $A c t,{ }^{115}$ are both vindications of the reproductive rights of private individuals. Yet their focus is on the decision not to have children. In respect of the Choice Act parties may within certain time frames legally terminate a pregnancy, ${ }^{116}$ while under the Sterilisation Act parties may choose to be sterilised to avoid a pregnancy. In a similar vein, the Children's Act ${ }^{117}$ contains provisions regarding access to contraceptives, ${ }^{118}$ which also promote an individual's right not to reproduce.

While certain provisions of the Children's Act acknowledge that children may be born as a result of artificial fertilisation ${ }^{119}$ and surrogacy, ${ }^{120}$ no

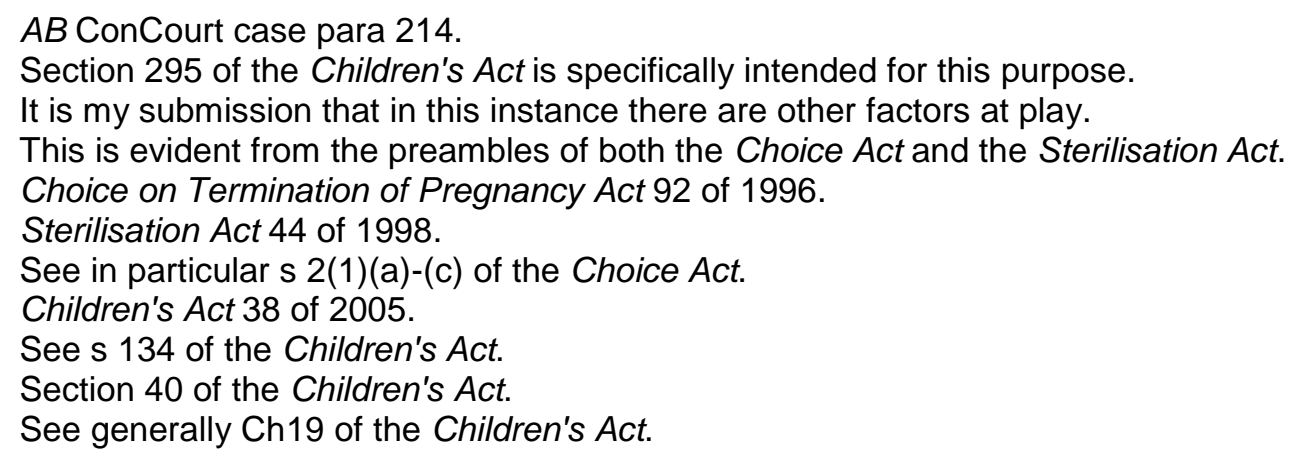


reference can be found in the wording of this act that recognises a right to reproduce noncoitally. ${ }^{121}$ Yet both artificial fertilisation and surrogacy are forms of noncoital reproduction. The argument could thus - by implication be made that the Children's Act recognises both the right not to have children as well as the right to do so.

A similar argument could be made regarding the National Health Act (NHA) and the Regulations Relating to Artificial Fertilisation of Persons (Regulations). ${ }^{122}$ The very existence of regulations regarding artificial fertilisation potentially affirms the right to reproduce noncoitally. However, the scope of this right is unclear in certain instances. For example, in respect of PHR, section 56(1) of the NHA states that only the gametes of live persons may be used. ${ }^{123}$ Section 62 further allows persons to make wills in which they donate their "bod[ies] or any specified tissue thereof to be used after [their] death". The tissues referred to exclude gametes according to the definition found in the NHA. The existence of these provisions thus suggests that PHR is not allowed. So while there may be a right to reproduce noncoitally, this right is available only to living individuals, regardless of the fact that the deceased person may have granted consent to use his or her gametes after death.

In respect of embryo donation: the Regulations state that parties who make use of donated gametes may have repeated recourse to the same genetic material, provided that a particular donor may not be used more than twelve times. ${ }^{124}$ There are, however, no corresponding provisions pertaining to embryo donation. Presumably the same rule applies to the use of embryos. Furthermore, the fact that consent may be obtained from the Minister to dispense with this rule suggests that a refusal on the part of the Minister could result in an argument that there has been an infringement of the recipients' rights. In this instance, the existence of this provision potentially confirms the existence of a right to reproduce noncoitally.

Mitochondrial donation, a relatively new medical development, which involves manipulation of gametes to produce a healthy child, is not referred to in the Regulations either directly or indirectly. The NHA, however, prohibits the manipulation of gametes outside of the human body for the purposes of reproductive cloning. ${ }^{125}$ This raises the question of whether or

\footnotetext{
121 This may be because the focus of this legislation is not on reproduction.

122 See $\mathrm{n} 14$ above.

123 This provision is echoed in reg 2 of the Regulations.

124 That is unless permission is obtained from the Minister of Health. See reg 7(2) of the Regulations.

125 Section 57 of the NHA.
} 
not mitochondrial donation qualifies as reproductive cloning. Bredenoord et al are of the opnion that it does not, as a transfer of mitochondria does not produce genetically identical offspring. ${ }^{126}$ The question of mitochondrial donation as an exercise of one's reproductive rights it thus left unanswered.

From the aforementioned, it is evident that while certain pieces of legislation clearly acknowledge the right not to have children, the same cannot unequivocally be said regarding the right to reproduce noncoitally. At most, legislation suggests that such a right exists. Yet full effect is not given to this right in certain cases of noncoital reproduction. It can thus be concluded that the existing legal framework for such a right is deficient in certain respects.

\section{Conclusion}

Developments in medical science and an increase in the use of noncoital reproduction have necessitated a shift in the way that reproductive rights have historically been defined. What was traditionally understood as incorporating a right to avoid reproduction, now potentially includes a right to reproduce noncoitally. At an international level, this new right may find protection under the right to private and family life; while at a local level it could form part of the right to make decisions regarding reproduction or the right to privacy, although the recent decision by the majority of the Constitutional Court in $A B \vee$ Minister of Social Development suggests otherwise. Clearly the decision by the majority is weak and open to criticism.

That said, the uncertainty regarding the constitutional basis of such a right suggests that an exposition of this right is thus needed, one which considers the scope and content of this right. Once clarity is achieved on this score, existing legislation should either be amended or new legislation drafted which gives full effect to a right to reproduce noncoitally.

\section{Bibliography}

\section{Literature}

Al-Nuaim and Jenkins 2007 SAJOG

Al-Nuaim $L$ and Jenkins $J$ "A Brief Historical Overview of Assisted Reproduction" 2007 SAJOG 38-41

Asch and Marmor "Assisted Reproduction"

Asch A and Marmor R "Assisted Reproduction" in Crowley M (ed) From Birth to Death and Bench to Clinic: The Hastings Centre Bioethics Briefing Book

126 Bredenoord, Pennings and De Wert 2008 Human Reproduction Update 671. 
for Journalists, Policymakers, and Campaigns (The Hastings Centre New York 2008) 5-9

Bell 2006 AJETS

Bell K "An Overview of Assisted Reproduction in Australia and Directions for Social Research" 2006 AJETS 15-27

Bernabeu 2007 BlOforum Europe

Bernabeu R "Development of Assisted Reproduction: Past, Present and Future of Technologies" 2007 BIOforum Europe 2-3

Blank 1997 Politics and the Life Sciences

Blank RH "Assisted Reproduction and Reproductive Rights: The Case of In Vitro Fertilization" 1997 Politics and the Life Sciences 279-288

Birenbaum 1996 SAJHR

Birenbaum J "Contextualising Choice: Abortion, Equality and the Right to Make Decisions" 1996 SAJHR 485-503

Bredenoord, Pennings and De Wert 2008 Human Reproduction Update Bredenoord AL, Pennings $G$ and De Wert G "Ooplasmic and Nuclear Transfer to Prevent Mitochondrial DNA Disorders: Conceptual and Normative Issues" 2008 Human Reproduction Update 669-678

Cohen and Sayeed 2011 J Law Med Ethics

Cohen IG and Sayeed S "Fetal Pain, Abortion, Viability and the Constitution" 2011 J Law Med Ethics 235-242

Currie and De Waal Bill of Rights Handbook

Currie I and De Waal J The Bill of Rights Handbook $6^{\text {th }}$ ed (Juta Cape Town 2013)

Davis Mattar 2008 SUR - International Journal on Human Rights

Davis Mattar L "Legal Recognition of Sexual Rights - A Comparative Analysis with Reproductive Rights" 2008 SUR - International Journal on Human Rights 61-83

Dimond 2015 British Medical Bulletin

Dimond R "Social and Ethical Issues in Mitochondrial Donation" 2015 British Medical Bulletin 173-182

Fasouliotis and Schenker 1999 Human Reproduction Update Fasouliotis SJ and Schenker JG "Social Aspects in Assisted Reproduction" 1999 Human Reproduction Update 26-39 
Freedman and Isaacs 1993 Studies in Family Planning

Freedman LP and Isaacs SL "Human Rights and Reproductive Choice" 1993 Studies in Family Planning 18-30

Grossman et al 2011 BMC Health Services Research

Grossman D et al"Surgical and Medical Second Trimester Abortion in South Africa: A Cross Sectional Study" 2011 BMC Health Services Research 224232

Guttmacher et al 1998 Int Perspect Sex Reprod Health

Guttmacher S et al "Special Report: Abortion Reform in South Africa: A Case Study of the 1996 Choice on Termination of Pregnancy Act" 1998 Int Perspect Sex Reprod Health 191-194

Kharb 2006 IJLHE

Kharb D "Assisted Reproductive Techniques Ethical and Legal Concerns" 2006 IJLHE 1-5

Kindregan and McBrien 2005 Fam $L Q$

Kindregan CP, Jr and McBrien M "Posthumous Reproduction" 2005 Fam L Q 579-595

Kindregan and McBrien Assisted Reproductive Technology

Kindregan CP, Jr and McBrien M Assisted Reproductive Technology: A Lawyer's Guide to Emerging Law and Science $2^{\text {nd }}$ ed (American Bar Association Chicago 2011)

Kruger and Botha Clinical Gynaecology

Kruger TF and Botha MH Clinical Gynaecology $4^{\text {th }}$ ed (Juta Claremont 2011)

Loubser and Midgley Law of Delict

Loubser M and Midgley R (eds) The Law of Delict in South Africa $2^{\text {nd }}$ ed (Oxford University Press Cape Town 2012)

Mascarenhas et al 2012 PLOS Medicine

Mascarenhas MN et al "National, Regional and Global Trends in Infertility Prevalence Since 1990: A Systematic Analysis of 277 Health Surveys" 2012 9(12) PLOS Medicine 1-12

Meyerson 1999 SALJ

Meyerson D "Abortion: The Constitutional Issues" 199915 SALJ 50-59

Ngwena $2004 \mathrm{~J}$ Law Med Ethics

Ngwena C "An Appraisal of Abortion Laws in Southern Africa from a Reproductive Health Rights Perspective" 2004 J Law Med Ethics 708-717 
Olaniyan Corruption and Human Rights Law

Olaniyan K Corruption and Human Rights Law in Africa (Hart Oxford 2014)

Orr and Siegler $2002 \mathrm{~J}$ Med Ethics

Orr RD and Siegler M "Is Posthumous Semen Retrieval Ethically Permissible?" 2002 J Med Ethics 299-303

O'Sullivan "Reproductive Rights"

O'Sullivan M "Reproductive Rights" in Woolman S et al (eds) Constitutional Law of South Africa (Juta Cape Town Revised Service 3 2011) 37-1 - 3728

Packer Right to Reproductive Choice

Packer CAA The Right to Reproductive Choice: A Study in International Law (Institute for Human Rights, Åbo Akademi University Turku 1996)

Peart 2015 VUWLR

Peart N "Life Beyond Death: Regulating Posthumous Reproduction in New Zealand" 2015 VUWLR 725-754

Pickles 2012 PELJ

Pickles C "Termination-of-Pregnancy Rights and Foetal Interests in Continued Existence in South Africa: The Choice on Termination of Pregnancy Act 92 of 1996" 2012 15(5) PELJ 403-434

Rebouche 2011 Ala L Rev

Rebouche R "The Limits of Reproductive Rights in Improving Women's Health" 2011 Ala L Rev 1-42

Robertson 1995 Fertility and Sterility

Robertson JA "Ethical and Legal Issues in Human Embryo Donation" 1995 Fertility and Sterility 885-894

Robey Posthumous Semen Retrieval and Reproduction

Robey C Posthumous Semen Retrieval and Reproduction: An Ethical, Legal, and Religious Analysis (MA-thesis Wake Forest University 2015)

Sarkin-Hughes 1993 THRHR

Sarkin-Hughes $J$ "A Perspective on Abortion Legislation in South Africa's Bill of Rights Era" 1993 THRHR 83-94

Shalev 2000 Health and Human Rights

Shalev C "Rights to Sexual and Reproductive Health: The ICPD and the Convention on the Elimination of All Forms of Discrimination against Women" 2000 Health and Human Rights 38-66 
Soini et al 2006 Eur J Hum Genet

Soini $S$ et al "The Interface between Assisted Reproductive Technologies and Genetics: Technical, Social, Ethical and Legal Issues" 2006 Eur J Hum Genet 588-645

Van der Bank 2012 EJBSS

Van der Bank CM "The Right to Privacy - South African and Comparative Perspectives" 2012 EJBSS 77-86

Van Niekerk 2015 PELJ

Van Niekerk C "Section 294 of the Children's Act: Do Roots Really Matter?" 2015 18(2) PELJ 398-428

Van Oosten 1999 SALJ

Van Oosten F "The Choice on Termination of Pregnancy Act: Some Comments" 1999 SALJ 60-76

\section{Case law}

\section{Australia}

Re Edwards 2011 NSWSC 478, 201181 NSWLR 198

\section{European Court of Human Rights}

Costa and Pavan v Italy Application No 54270/10 of 28 August 2012

Dickson $v$ the United Kingdom Application No 44362/04 of 4 December 2007

Evans $v$ the United Kingdom Application No 6339/05 of 10 April 2007

Knecht v Romania Application No 10048/10 of 2 October 2012

Nedescu v Romania Application No 70035/10 of 6 November 2012

Parrillo v Italy Application No 46470/11 of 27 August 2015

SH v Austria Application No 57813/00 of 3 November 2011

\section{South Africa}

AB v Minister of Social Development 20162 SA 27 (GP)

AB v Minister of Social Development 20173 BCLR 267 (CC)

Barnard v Santam Bpk 19991 SA 202 (SCA)

Bernstein v Bester 19962 SA 751 (CC) 
Christian Lawyers Association of SA v Minister of Health 19984 SA 1113 (T)

Christian Lawyers Association v Minister of Health 20051 SA 509 (T)

Clinton-Parker $v$ Administrator, Transvaal; Dawkins $v$ Administrator, Transvaal 19962 SA 37 (W)

Majiet v Santam Ltd 19974 All SA 555 (C)

Minister of Home Affairs v Fourie 20061 SA 524 (CC)

NM v Smith 20075 SA 250 (CC)

Road Accident Fund v Sauls 20022 SA 55 (SCA)

\section{United Kingdom}

L v Human Fertilisation and Embryology Authority 2008 EWHC 2149 (Fam) $R v$ Human Fertilisation and Embryology Authority, exp Blood 19963 WLR $1176(\mathrm{QB})$

$R$ (on the Application of M) v Human Fertilisation and Embryology Authority 2015 EWHC 1706 (Admin)

\section{Legislation}

\section{South Africa}

Abortion and Sterilisation Act 2 of 1975

Children's Act 38 of 2005

Choice on Termination of Pregnancy Act 92 of 1996

Constitution of the Republic of South Africa, 1996

National Health Act 61 of 2003

Sterilisation Act 44 of 1998

International instruments

African Charter on Human and Peoples' Rights (1981)

Convention on the Elimination of All Forms of Discrimination against Women (1979) 
European Convention for the Protection of Human Rights and Fundamental Freedoms (1950)

International Covenant on Civil and Political Rights (1966)

Universal Declaration of Human Rights (1948)

\section{Government publications}

GN 1165 in GG 40312 of 30 September 2016

\section{Internet sources}

ASRM 2015 https://www.asrm.org/uploadedFiles/ASRM_Content/ Resources/Patient_Resources/Fact_Sheets_and_Info_Booklets/ART.pdf American Society for Reproductive Medicine 2015 Assisted Reproductive Technology: A Guide for Patients https://www.asrm.org/uploadedFiles/ ASRM_Content/Resources/Patient_Resources/Fact_Sheets_and_Info_Bo oklets/ART.pdf 1-32 accessed 30 January 2017

Anon $1998 \mathrm{http}: / / w w w . s a h i s t o r y . o r g . z a / d a t e d-e v e n t / a p p l i c a t i o n-p r e t o r i a-$ supreme-court-declare-freedom-choice-terminate-pregnancy-lawuncons\#sthash.6n2PzNLG.dpuf

Anonymous 1998 An Application to the Pretoria Supreme Court, to Declare the Freedom of Choice to Terminate Pregnancy Law Unconstitutional, Fails http://www.sahistory.org.za/dated-event/application-pretoria-supremecourt-declare-freedom-choice-terminate-pregnancy-law-uncons\#sthash. 6n2PzNLG.dpuf_accessed 31 March 2016

Anon 2004 http://www.news24.com/SouthAfrica/News/Teens-given-rightto-abortion-20040528

Anonymous 2004 Teens Given Right to Abortion http://www.news24.com/SouthAfrica/News/Teens-given-right-to-abortion20040528 accessed 14 May 2016

Anon 2006 http://www.news24.com/SouthAfrica/Politics/Abortion-Actdeclared-invalid-20060817

Anonymous 2006 Abortion Act Declared Invalid http://www.news24.com/SouthAfrica/Politics/Abortion-Act-declared-invalid20060817 accessed 14 May 2016

Anon 2008 http://www.news24.com/SouthAfrica/Politics/Parliamentrelaxes-abortion-law-20080207

Anonymous 2008 Parliament Relaxes Abortion Law http://www.news24.com/SouthAfrica/Politics/Parliament-relaxes-abortionlaw-20080207 accessed 14 May 2016 
Centre for Reproductive Rights 1998 http://www.reproductiverights. org/sites/default/files/documents/SRSouthAfrica98en.pdf

Centre for Reproductive Rights 1998 Women's Reproductive Rights in South Africa: A Shadow Report http://www.reproductiverights.org/ sites/default/files/documents/SRSouthAfrica98en.pdf accessed 14 June 2016

Collins Dictionary date unknown http://www.collinsdictionary. com/dictionary/english/noncoital

Collins Dictionary date unknown Noncoital http://www.collinsdictionary. com/dictionary/english/noncoital accessed 31 May 2016

Dictionary.com date unknown_http://www.dictionary.com/browse/ asexual-reproduction

Dictionary.com date unknown Asexual Reproduction http://www.dictionary.com/browse/asexual-reproduction accessed 31 May 2016

ECtHR 2015 http://www.echr.coe.int/Documents/FS_Reproductive_ENG. pdf

European Court of Human Rights 2015 Factsheet-Reproductive Rights http://www.echr.coe.int/Documents/FS_Reproductive_ENG.pdf_accessed 8 June 2016

Gallagher 2015 http://www.bbc.com/news/health-31594856

Gallagher J 2015 UK Approves Three-person Babies http://www.bbc.com/news/health-31594856 accessed 27 February 2015

Human Fertilisation and Embryology Authority 2012 http://www.hfea.gov.uk/161.html

Human Fertilisation and Embryology Authority 2012 Human Embryo Research http://www.hfea.gov.uk/161.html accessed 29 March 2016

Human Fertilisation and Embryology Authority 2014 http://www.hfea.gov.uk/docs/2014-10-

01_Mitochondrial_donation_an_introductory_briefing_note_-_final.pdf Human Fertilisation and Embryology Authority 2014 Mitochondrial Donation: An Introductory Briefing Note http://www.hfea.gov.uk/docs/201410-01_Mitochondrial_donation_an_introductory_briefing_note_-_final.pdf accessed 16 June 2016

Illumina 2014 http://www.illumina.com/content/dam/illumina-marketing/ documents/ clinical/karyomapping-clinicians.pdf 
Illumina 2014 Karyomapping: A Rapid PDG Solution for Single Gene Disorders http://www.illumina.com/content/dam/illumina-marketing/ documents/clinical/ karyomapping-clinicians.pdf accessed 1 April 2015

Kelland and Maclellan 2015 http://in.reuters.com/article/us-health-babiesidINKBNOL710B20150203

Kelland K and Maclellan K 2015 Britain Votes to Allow World's First "Threeparent" IVF Babies http://in.reuters.com/article/us-health-babiesidINKBNOL710B20150203 accessed 27 February 2015

Krans 2015 http://www.healthline.com/health-news/women-freezing-eggsso-they-can-work-now-and-have-kids-later-072015\#2

Krans B 2015 Women Freezing Eggs So They Can Work Now and Have Kids Later http://www.healthline.com/health-news/women-freezing-eggsso-they-can-work-now-and-have-kids-later-072015\#2_accessed 2 June 2016

Merriam-Webster date unknown http://www.merriam-webster.com/ dictionary/asexual

Merriam-Webster date unknown Asexual http://www.merriamwebster.com/dictionary/asexual accessed 31 May 2016

Mussen 2015 http://www.stuff.co.nz/national/health/67539030/hope-fordead-teens-sperm

Mussen D 2015 Hope for Dead Teen's Sperm http://www.stuff.co.nz/national/health/67539030/hope-for-dead-teenssperm accessed 30 March 2015

Parry 2015 http://www.dailymail.co.uk/health/article-3078210/Numberwomen-freezing-eggs-soars-400-one-year-careers-prioritisedmotherhood.html

Parry L 2015 Number of Women Freezing Their Eggs Soars By 400\% in One Year as Careers are Prioritised Over Motherhood http://www.dailymail.co.uk/health/article-3078210/Number-womenfreezing-eggs-soars-400-one-year-careers-prioritised-motherhood.html accessed 2 June 2016

Rettner 2013 http://www.livescience.com/28652-made-to-order-embryoslegal-ethical-issues.html

Rettner R 2013 Made-to-Order Embryos Create New Legal Issues http://www.livescience.com/28652-made-to-order-embryos-legal-ethicalissues.html accessed 24 March 2017 
Rushton 2014 http://www.telegraph.co.uk/finance/jobs/10681161/Womenare freezing-their-eggs-as-part-of-a-career-strategy.html

Rushton K 2014 Women are Freezing Their Eggs as Part of a Career Strategy http://www.telegraph.co.uk/finance/jobs/10681161/Women-arefreezing-their-eggs-as-part-of-a-career-strategy.html accessed 2 June 2016

Sidley 1998 http://www.bmj.com/content/316/7146/1696.2.full

Sidley P 1998 South Africa's Liberal Abortion Laws Challenged http://www.bmj.com/content/316/7146/1696.2.full accessed 31 March 2016

Snow and Knopff 2012 https://papers.ssrn.com/sol3/ papers.cfm?abstract_id=2056442

Snow D and Knopff R 2012 Assisted Reproduction Policy in Federal States: What Canada Should Learn from Australia https://papers.ssrn.com/sol3/papers.cfm?abstract_id=2056442 accessed 25 April 2017

UN $2014 \quad$ http://www.ohchr.org/Documents/Publications/NHRI Handbook.pdf

United Nations 2014 Reproductive Rights are Human Rights: A Handbook for National Human Rights Institutions http://www.ohchr.org/ Documents/Publications/NHRIHandbook.pdf accessed 3 February 2016

UN Population Fund 2014 http://www.unfpa.org/sites/default/files/pubpdf/programme_of_action_Web\%20ENGLISH.pdf

United Nations Population Fund 2014 Programme of Action http://www.unfpa.org/sites/default/files/pub-

pdf/programme_of_action_Web\%20ENGLISH.pdf accessed 2 April 2015

UN Women date unknown http://www.un.org/womenwatch/daw/beijing/ UN Women date unknown Beijing and Its Follow Up http://www.un.org/womenwatch/daw/beijing/ accessed 2 April 2015

WHO date unknown http//www.who.int/reproductivehealth/topics/infertility/ definitions/en/

World Health Organisation date unknown Infertility Definitions and Terminology http://www.who.int/reproductivehealth/topics/ infertility/definitions/en/_accessed 14 March 2016

WHO 2009 http://www.who.int/reproductivehealth/publications/infertility/art - terminology.pdf

World Health Organisation 2009 The International Committee for Monitoring Assisted Reproductive Technology (ICMART) and the World Health 
Organization (WHO) Revised Glossary on ART Terminology, 2009 http://www.who.int/ reproductivehealth/publications/infertility/art_ terminology.pdf accessed 14 March 2016

\section{LIST OF ABBREVIATIONS}

ACHPR

AJETS

Ala L Rev

ART

ASRM

CEDAW

ECHR

ECtHR

EJBSS

Eur J Hum Genet

Fam L Q

ICCPR

ICPD

IJHLE

Int Perspect Sex Reprod Health

IVF

J Law Med Ethics

$J$ Med Ethics

$\mathrm{NHA}$

PELJ

PGD

PHR

SAJHR
African Charter on Human and Peoples' Rights

Australian Journal of Emerging Technologies and Society

Alabama Law Review

Assisted Reproductive Technologies

American Society for Reproductive

Medicine

Convention on the Elimination of All forms of Discrimination against Women

European Convention for the Protection of Human Rights and Fundamental Freedoms

European Court of Human Rights

European Journal of Business and Social Sciences

European Journal of Human Genetics

Family Law Quarterly

International Covenant on Civil and Political Rights

International Conference on Population and Development

Internet Journal of Law, Healthcare and Ethics

International Perspectives on Sexual and Reproductive Health

In Vitro Fertilisation

Journal of Law, Medicine and Ethics

Journal of Medical Ethics

National Health Act

Potchefstroom Electronic Law Journal

Pre-implantation Genetic Diagnosis

Posthumous Reproduction / Conception

South African Journal on Human Rights 
SAJOG

SALJ

THRHR

UDHR

UN

UK

VUWLR

WHO
South African Journal of Obstetrics and Gynaecology

South African Law Journal

Tydskrif vir Hedendaagse RomeinsHollandse Reg

Universal Declaration of Human Rights

United Nations

United Kingdom

Victoria University of Wellington Law

Review

World Health Organisation 